\title{
A feltétel nélküli alapjövedelem megítélésének empirikus elemzése YouTube hozzászólásokon keresztül $^{1}$
}

\author{
OLÁH ESZTER ${ }^{2}$
}

\begin{abstract}
ABSZTRAKT
Az online térben nagy népszerüségnek örvend a világ egyik legnagyobb videómegosztó platformja, a YouTube, ahol a nézők véleményezhetik a videókat és azok témáit. A tanulmány célja annak vizsgálata, hogy a napjaink gazdasági-társadalmi változásaival párhuzamosan egyre nagyobb figyelmet kapó feltétel nélküli alapjövedelemmel kapcsolatban hazánkban milyen értékek és vélemények rajzolódnak ki a YouTube ilyen témájú videóinak kommentszekciójában. Kutatásunk vegyes módszerrel dolgozik, az adatok gyújtése, tárolása, szentimentanalízise és a szózsák módszere informatikai eljárásokkal valósult meg, míg a kategorizálás kézi kódolás révén. A szentimentanalízis eredménye mutatja, hogy a pozitív érvek kisebb arányban merülnek fel a megjegyzésekben. Olyan értékjellemzőkkel bírnak, mint a befogadás, a létjogán elv, az igazságosság és a szabadság hangsúlyozása. A pozitív érvek közül a legmagasabb támogatottságot a megvalósíthatóság képezi. A negatív kategóriájú értékek gyakrabban merülnek fel, így a másodrangú lét, igazságtalanság, kirekesztés, megfizethetetlenség és a teljesítményelvúség értékeinek hangsúlyozása domináns az elemzett megjegyzésekben.
\end{abstract}

KULCSSZAVAK: szövegbányászat, számítógépes szövegelemzés, szentimentanalízis, feltétel nélküli alapjövedelem, munkaalapú társadalom

\section{ABSTRACT}

\section{Empirical analysis of the judgment of unconditional basic income through YouTube comments}

One of the world's largest video-sharing platforms is YouTube, where viewers can comment on the videos and their topics. The aim of this study is to examine the values and opinions about unconditional basic income according to the comment sections of several Youtube's videos which topic is the previously mentioned UBI which is receiving increasing attention in parallel with today's economic and social changes. Our research works with a mixed method, data collection, storage, sentiment analysis and the bag of words method which were implemented using IT procedures, while categorization was done through manual coding. The results of the sentiment

${ }^{1}$ A publikáció elkészítését az EFOP-3.6.1-16-2016-00022 számú projekt támogatta. A projekt az Európai Unió támogatásával, az Európai Szociális Alap társfinanszírozásával valósult meg.

${ }^{2}$ Debreceni Egyetem Humán Tudományok Doktori Iskola Szociológia és Társadalompolitika Doktori Program, olah.eszter@arts.unideb.hu 


\section{TEMATIKUS TANULMÁNYOK - Digitális szociológia}

analysis show that positive arguments appear to a lesser extent in the comments. Positive arguments have value characteristics such as inclusion, the principle of the right to exist, justice and freedom. Among the positive arguments feasibility enjoys the highest support. Negative category values arise more frequently, so the emphasis on the values of injustice, exclusion, unaffordability, and performance-orientation is dominant in the analyzed comments.

KEYWORDS: text mining, computer text analysis, sentiment analysis, unconditional basic income, work-based society

\section{Bevezetés}

Napjainkban egyre nagyobb jelentőséget kapnak a társadalmi folyamatok megértésében a digitális adatok. A világon előállított információ mennyisége gyors ütemben növekszik és egyre nagyobb mértékben digitálisan kerülnek tárolásra, ezen digitális adatokat tekinthetjük Big Data-nak (Salganick 2017). A nagy adathalmazok számításigényes analizálása során mintázatokat és összefüggéseket lehet feltárni, különösen az emberi viselkedés és interakciók terén. Az ilyen típusú információk a társadalomtudományokat olyan vélemények és attitűdök feltárásához vezetheti, amelyek nem érhetőek el a hagyományos módszerek segítségével, vagy azért, mert a téma érzékeny elemeket érint, vagy azért, mert nehéz a megfelelő operacionalizálás (Németh et al. 2020).

Jelen tanulmány nyilvános YouTube videókhoz íródott kommenteken végzett elemzést, a feltétel nélküli alapjövedelem témakörére fókuszálva. Ezen adathalmaz nagysága mellékes abból a szempontból, hogy Big Data-alapúnak tekinthető-e, ennek a kérdésnek az eldöntésében a szövegekre jellemző strukturálatlanságot és a standardizálatlanságot vettük meghatározónak (Németh et al. 2020).

A közösségi média platformjai és a videómegosztó oldalak jelentőségének felértékelődése is hozzájárul a digitális adatok növekedéséhez. Ezeken a felületeken a magatartásbéli elköteleződést általában szimbolikusan fejezi ki az egyén, a kedveléseken, a megjegyzések írásán vagy a megosztásokon keresztül (Dubovi - Tabak 2021). Ezeken a felületeken a felhasználó dönthet úgy, hogy csendes megfigyelőjeként az eseményeknek passzív tartalomfogyasztó szerepben marad. Illetve választhatja azt is, hogy aktív szereplőként bekapcsolódik a különböző interakciókba (Khan 2017). Egy adott oldal vagy poszt követése és kedvelése a közösségi oldalakon magas fokú érdeklődést és kötődést mutat az adott téma iránt (Salganick 2017). A passzív megfigyelői szereptől jóval aktívabb és magasabb szintű érdeklődést takar a megjegyzések közzététele (kommentelés). Az, hogy az egyén képes bekapcsolódni az érvelés folyamatába - válaszol más személyek megjegyzéseire, kijelentéseket tesz, állításokat cáfol meg vagy támaszt alá - egyfajta kognitív elköteleződést jelent, mely során a kommentelés aszinkron jellege miatt a hozzászólónak lehetősége van arra, hogy átgondolja véleményét és információt gyüjtsön az adott témára vonatkozóan, mielőtt közzéteszi gondolatait (Lucas et al. 2014). 


\section{TEMATIKUS TANULMÁNYOK - Digitális szociológia}

A koronavírus-járvány tovább növelte a digitalizáció jelentőségét a mindennapjainkban, a távoktatás és a home office által. Továbbá gazdasági és társadalmi változásokat (munkahelyek bezárása, szolgáltatások leállása) tapasztalhattunk meg, melyek gyors és rugalmas alkalmazkodást igényeltek. A pandémia hatására beszűkült pénzkereseti lehetőségek gazdasági és szociálpolitikai intézkedéseket sürgettek, mivel a munka nélkül maradt egyének ellátásának biztosítása világszerte kulcskérdéssé vált. Ezen folyamatok aktualizálták a feltétel nélküli alapjövedelem 19. század óta felmerülő gondolatát. A feltétel nélküli alapjövedelem egy rendszeres időközönként fizetett készpénzjuttatást takar, mely univerzalitásából fakadóan mindenkire kiterjed, elhagyva a rászorultsági vizsgálatot és a munkakötelezettség megszabását (Van Parijs 2010). Az alapjövedelem köztudatban tartása annak köszönhető, hogy támogatói szerint a 21. század kihívásaira megoldási javaslatként szolgálhat, hiszen egyszerre képes megteremteni a szabadabb döntéshozatal lehetőségét a munkavégzés terén és a diszkriminációmentes szociális ellátórendszert (Beck 2010).

Jelen kutatás fókuszpontja egy nehezen kutatható kérdéskörnek tekinthető, hiszen az emberek nem rendelkeznek az alapjövedelemmel kapcsolatosan személyes tapasztalattal, mivel hazánkban nem került bevezetésre egy ilyen univerzális juttatás. Ezért a YouTube platformján a témához kapcsolódó videókhoz íródott megjegyzések elemzésével szeretnénk jobban megérteni a hozzászólók attitűdjeit ezen gazdaságpolitikai eszközzel kapcsolatban. Az alapjövedelem köznyelvi értelmezése sokszínűbb, mint ahogyan a szakirodalom alkalmazza Van Parijs fogalmi lehatárolását. A média résztvevői, a politikai pártok kampányai és az egyes országok kísérleti programjai igen sokféle tartalommal használják a fogalmat. Az általunk elemzett kommentek esetében sem lehetséges pontosan meghatározni, hogy milyen definíció szerint alkotnak véleményt az alapjövedelemmel kapcsolatban a kommentelők. Mindezt figyelembe véve jelen kutatásunk arra helyezi a hangsúlyt, hogy megvizsgálja hozzászólásaik során milyen tartalommal töltik meg a vitában résztvevők az alapjövedelem fogalmát és ehhez az általuk használt fogalomhoz milyen reflexiókat és félelmeket társítanak.

A tanulmány első részében összefoglaljuk a feltétel nélküli alapjövedelem értelmezési lehetőségeit, majd az empirikus kutatásunk adataira építve elemezzük a videómegosztó platformon található megjegyzéseket, hogy kiderítsük milyen jellegzetes értékminták mutathatók ki ezen gazdaságpolitikai eszközzel kapcsolatban az online felület felhasználói között.

\section{A feltétel nélküli alapjövedelem értelmezési lehetőségei}

A Van Parijs által használt fogalom szerint múködő alapjövedelem típusú juttatást Magyarországon még nem vezettek be. Mégis visszatérő eleme a média hírközléseinek, a közgazdasági és szociológiai diskurzusoknak, ahol vita folyik arról, hogy meg- 


\section{TEMATIKUS TANULMÁNYOK - Digitális szociológia}

valósítható-e egy ilyen típusú gazdaságpolitikai eszköz. A feltétel nélküli alapjövedelem megítélése nem tekinthető egységesnek. A viták négy fő kérdés körül bontakoznak ki (Gilbert et al. 2018):

Mennyiben megfizethető egy alapjövedelem típusú univerzális juttatás (finanszírozás):

Egy jóléti juttatás esetén kulcskérdés, hogy hosszú távon mennyiben fenntartható. A jóléti programok és az azokkal járó adóterhek nagysága meghatározzák a jóléti államokkal kapcsolatos vitákat (Tomka 2008). Az univerzális jóléti rendszerek működési rendjét élesen bírálják, mivel olyanok is részesednek az ilyen típusú juttatásokban, akik egyébként nem szorulnak rá. Így az ilyen elven működő rendszerek legnagyobb hibájának tekinthető a célzást figyelembe véve az egyéni szükségletek figyelmen kívül hagyása. A finanszírozhatóság és a finanszírozhatatlanság álláspontja mellett közel azonos arányban hozhatók fel érvek és ellenérvek, legyen szó bármilyen típusú jóléti juttatásról. Így a kérdés az, hogy a jóléti programoknak a társadalmi következményei inkább pozitívan, vagy negatívan ítélhetők-e meg, mivel ez megmutatja, hogy mennyiben éri meg a finanszírozással járó esetleges gazdasági következmények terhét felvállalni.

Mennyiben értelmezhető alapvető jogként a társadalom tagjai számára (filozófia):

Magyarországra - számos közép-európai országhoz hasonlóan - egy olyan érték jellemző, amelynek során erőteljesen jelen van a szociális dilemma problémája (Sachs 2015). A dilemma lényege tulajdonképpen az, hogy az egyes egyének mennyiben hajlandóak költségeket vállalni a közösség egészének érdekében, tudva, hogy ezzel a gazdaság működésének javulása is elérhető, ami az egyén életére is pozitív hatást gyakorolhat. A védelemhez való jogot azért lehet követelni, mert kollektív érvényü és törvényileg intézményesített garanciákat jelent, amik függetlenek az egyén személyes tulajdonságaitól és érdemeitől (Castel 2005b). Kérdés, hogy alapjövedelem esetén az egyének alapvető jogként ismernek-e el bármilyen szintű támogatást a magasabb életszínvonal érdekében vagy úgy vélik, hogy mindenki maga felelős saját boldogulásáért.

Mennyiben megvalósítható a hozzá kapcsolódó érdekek metszetében (megvalósíthatóság):

Az a morális gondolat, miszerint a boldog és produktív lakosság növekvő szabadideje jelentős veszélyt jelenthet a fennálló rendre nézve, a mai napig fenntartja társadalmunkban azt a nézetet, hogy a munka az önmegvalósítás eszköze (Graeber 2018). A munkavégzés felemészti az ébren töltött idő nagyobb részét és már csak arra marad ideje az egyénnek, hogy a fogyasztói örömök kielégítésére szánjon időt. Graeber nézete szerint a munkavégzés önmagában erkölcsi értéket jelent, aki pedig nem hajlandó magát munkafegyelem alá vetni az nem is érdemel támogatást. Ennek a gondolkodásmódnak a fenntartása érdekében igyekeznek lekötni a dolgozókat, akár olyan munkákkal is, amelyek a gazdaság számára nem szükségesek. Graeber 


\section{TEMATIKUS TANULMÁNYOK - Digitális szociológia}

igazgatási feudalizmusnak nevezi a fennálló rendszert, melyet a gazdasági erők ösztönöznek. Amiben azért dolgozunk többet, mert az uralja gondolkodásunkat, hogy a fogyasztói örömök utáni vágyakozást fáradtságos munkával lehet kielégíteni, ahogyan ez a weberi gondolatokban is megjelenik. Eszerint a piaci munkát a jövedelmi hasznon túl, elvi kötelességként végzi az ember, így a produktív és hasznos munka hozzátartozik a jelentőségteljesnek vélt emberi élethez (Weber 1982). A feltétel nélküli alapjövedelemmel kapcsolatban az egyik leggyakoribb félelem, hogy csökkentené a munkavállalási motivációt, azáltal, hogy a jövedelmet elválasztja a munkaerőpiaci részvételtől (Bergmann 2004). A feltétel nélküli jelleg veszélyeztetné azt a hozzáállást, hogy a produktív és hasznos munka hozzátartozik a jelentőségteljesnek vélt emberi élethez. A kevesebb munkavállaló hatással lenne a fogyasztás csökkenésére is, ami mérsékelné a gazdaság növekedési ütemét (Baksay et al. 2017). Ez azt eredményezné, hogy a tőke a kedvezőbb befektetési terület felé vándorolna. A tőke elvándorlásának igazi veszélyét a döntéshozói és politikai körök érzékelik, hiszen az alapjövedelem veszélyeztetné a tőke hatékonyságát, a profitra irányuló termelést (Artner 2014).

Mennyiben gyakorol ellenösztönző hatást a munkavállalásra (motiváció):

A munka jelentőségének fennmaradása mellett szól az ember belső indíttatása, a kényszerítő erő a cselekvésre, a semmittevés helyett, azért, hogy az egyén életében az örökös hiányt kielégíthesse (Keynes 1965, Fromm 2002). Mivel nem az alapvető fiziológiai szükségleteink képezik a cselekvésre való indíttatás alapját, hanem egy mélyebb késztetés, az emberi akarat (Schopenhauer 1992), így a feltétel nélküli alapjövedelem a munkavégzés kényszer jellegének feloldásán túl és az alapvető fiziológiai szükségletek kielégítésén túl a belső faktorokra nehezen tudna hatást gyakorolni. Mivel a felhalmozási vágyat nem tudná kielégíteni és a munka pszichológiai jelentőségét is csak nehezen tudná pótolni. Hiszen az alapjövedelem egyrészt az alapvető szükségletek kielégítését tenné lehetővé és nem az addigi megszokott életszínvonalat (Beck 2010). Másrészt az alapjövedelem a munka kényszere alól szabadít fel, nem pedig az értelmes munkavégzés alól. Annak ellenére, hogy a kapitalizmus alapját a munka adja, mely identitást biztosít a munkavállaló számára, Szelényi (2014) úgy tartja, hogy mindig lesznek olyanok, akiket nem ösztönözne munkavállalásra egy feltétel nélküli juttatás és garantált munkanélküli ellátásként funkcionálna számukra.

A kutatás elméleti hátteréből látható, hogy a feltétel nélküli alapjövedelem nem értelmezhető egyoldalúan. Ezen gondolatok mentén a következő kutatási kérdések fogalmazódnak meg, melyekkel jobban megérthető a társadalom viszonyulása a feltétel nélküli alapjövedelemhez:

Milyen központi fogalmak alkotják a kutatás YouTube kommentár korpuszát, amelyek megalapozzák a társadalom értelmezését a feltétel nélküli alapjövedelmet illetően? 


\section{TEMATIKUS TANULMÁNYOK - Digitális szociológia}

Milyen megítélés alá esik a YouTube megjegyzésekben a feltétel nélküli alapjövedelem, mely az elemzett online felület felhasználóinak viszonyulását fejezi ezen eszközzel kapcsolatban?

Milyen értékminták jellemzőek az alapjövedelemmel kapcsolatos YouTube megjegyzések íróira?

\section{Módszertan}

\section{ADATGYÚJTÉS}

A YouTube az egyik legnagyobb online platform, melynek világszerte havonta több mint 2 milliárd bejelentkezett felhasználója van ${ }^{3}$. Ilyen magas nézettség mellett a társadalmi kérdésekkel foglalkozó videók jelentős hatással lehetnek a nézők véleményformálására. Tang és munkatársai megállapították, hogy a YouTube kevésbé kitett ennek a befolyásnak, hiszen ezen a platformon a felhasználók konkrétan keresnek rá arra (célorientált keresés), ami őket érdekli, ez gátolja a félretájékoztatás valószínűségét (Tang et al. 2021).

Mivel a feltétel nélküli alapjövedelem széles körben nem került bevezetésre Magyarországon, így a társadalom tagjai személyes tapasztalatokkal nem rendelkeznek ezen gazdaságpolitikai eszközzel kapcsolatban. Azt feltételezzük azonban, hogy a YouTube videók megtekintése pontosabb betekintést enged a kommentelők számára az alapjövedelem alkalmazásának feltételrendszerébe, jóllehet bizonyítékunk arra vonatkozóan nincs, hogy a vélemény írója a videó megtekintését követően, vagy attól függetlenül fogalmazta-e meg véleményét. A videókhoz füzött kommentek elemzése azonban mindkét esetben (megtekintette, illetve nem tekintette meg a videót teljes hosszában) hasznos információval szolgálhat arra vonatkozóan, hogy a kommentelők társadalma hogyan értelmezi ezt a jóléti juttatást.

A YouTube videók keresése 2021. február 28-án zajlott keresztmetszeti kutatásként, a „feltétel nélküli alapjövedelem” és „alapjövedelem” kifejezésekre történő kereséssel. A keresést inkognitó módban végeztük, elkerülve a felhasználói fiókhoz kapcsolódó preferenciákat, melyeket a YouTube figyelembe vesz a gépi-tanulás alapú ajánlások révén, melyek a platform algoritmusa szerint múködnek. Többirányú keresést folytattunk célorientált keresés alkalmazásával, egyrészt relevancia szerinti rendezés, másrészt megtekintések száma szerinti rendezés szerint, a minél szélesebb lefedettség érdekében. Az esetlegesen megjelenő duplikált videók törlésre kerültek. A videóknál fontos kritérium volt, hogy három percnél hosszabb tartalom legyen, hogy képes legyen annyi információt szolgáltatni, ami diskurzust alakít ki a kommentszekcióban. Azon videók nem kerültek kiválasztásra, melyeknél a meg-

\footnotetext{
${ }^{3}$ https://www.youtube.com/intl/hu/about/press/
} 


\section{TEMATIKUS TANULMÁNYOK - Digitális szociológia}

jegyzések írásának lehetőségét kikapcsolta a videót megosztó személy. Továbbá nem kerültek a mintába azon videók kommentjei sem, melyek tíznél kevesebb hozzászólással rendelkeznek. A videókat a kutatók nem tekintették meg, hiszen a kutatás fókuszában nem a videók tartalma áll. Objektív minta kialakítására törekedtünk annak érdekében, hogy meghatározhassuk, hogy az átlag felhasználó milyen képet alakít ki az alapjövedelem témakörével kapcsolatosan, politikai hovatartozástól függetlenül. Annak ellenére, hogy a közgondolkodásban a téma átpolitizált, törekedtünk arra, hogy mind támogatói, mind elutasítói oldalról széles körben jelenítsünk meg véleményeket.

A végső elemzésbe 22 videó került, melyek hosszú időszakot ölelnek fel, hiszen a videók 2013 és 2021 között készültek. Az empíria alapjául szolgáló megjegyzések kigyüjtésére a YouTube $\mathrm{API}^{4}$ segítségével került sor. ${ }^{5} \mathrm{~A}$ videókhoz készített adatbázis többek között a következő metaadatokat tartalmazta: videóazonosító (videóhoz hozzárendelt ID és URL), a videókhoz kapcsolódó megjegyzések, megjegyzések kedvelésének száma, közzétételük időpontja. Az adatbázis tartalmazta egyrészt az „eredeti megjegyzéseket”, melyek közvetlenül a videóhoz kapcsolódtak, másrészt a „megjegyzéshez füzött megjegyzéseket” is (úgynevezett „reply”), ami egy másik kommenthez érkezett válaszként.

Egy videó esetén maximum 100 komment gyűjthető a YouTube API segítségével, melyek a mások által legkedveltebb gondolatoknak minősülnek. A legtöbb kedvelést kapó megjegyzések tartalma jelzi a legjellemzőbb megközelítését az adott témának. Ahogyan az a bevezetőben elhangzott egy adott poszt kedvelése a közösségi oldalakon magas fokú érdeklődést és kötődést mutat az adott téma iránt (Salganick 2017). Mivel sokan lehetnek olyanok, akik úgy fejezik ki véleményüket, hogy nem írnak megjegyzést az adott videó alá, de a kedvelés lehetőségét használva kifejezik egyetértésüket. Azonban fontos megjegyezni, hogy a YouTube felhasználók véleménynyilvánítása nem tekinthető reprezentatívnak a magyar társadalom egészére nézve.

A videókat sorszámmal különböztettük meg az elemzés során, címeiket adatvédelmi okokból nem publikáljuk, hogy harmadik személy számára ne legyen visszakereshető az egyes megjegyzések forrása. Hazánkban a közösségi média adatainak elemzésekor a Facebook kínál elsődleges terepet a szöveges adatok kinyerésére, mivel a Twitter használata még kevésbé elterjedt. A 2018-as adatvédelmi botrány után a Facebook szigorúan korlátozta a Facebook API-n keresztül elérhető adatok körét a független kutatók számára (Ben-David 2020).

Ezzel szemben YouTube API rendelkezésre bocsájtja a kigyüjtött kommenteket, így nyilvánosnak tekinthetők az ott elérhető adatok, ami azt jelenti, hogy megtekinthetők az adatforrás előfizetése nélkül és a megjegyzés írójának kifejezett engedélye

\footnotetext{
${ }^{4}$ Application Programming Interfaces - alkalmazásprogramozási felület

${ }^{5}$ Ezúton szeretnék köszönetet mondani Tóth Ákosnak a módszertan során fellépő programozási feladatok megvalósításáért.
} 


\section{TEMATIKUS TANULMÁNYOK - Digitális szociológia}

nélkül. A legetikusabb eljárásmód szerint eljárva, az elemzés során az adatbázisunkból eltávolításra kerültek a felhasználónevek és elkerüljük a kommentek szószerinti idézését és a szabad átfogalmazásukat is. Mivel a kutatás etikája azt kívánja meg, - adatvédelem szempontból - hogy ha lehetséges mellőzni kell a pontos idézéseket, mivel így biztosítható annak elkerülése, hogy a felhasználók beazonosításra kerüljenek (Reilly 2014). A hozzáférhető adatok nem tartalmaznak személyes információkat, mint név, kor, lakhely, vagy iskolai végzettség, így az adatbázis csak összesített információkat használ, és nem teszi lehetővé szocio-demográfiai háttérre irányuló következtetések levonását ${ }^{6}$.

\section{ADATTISZTÍTÁS}

Az API segítségével leszűrt megjegyzésekből előállt a szöveges adatbázisunk, ami több szűrésen esett át az előfeldolgozási fázis előtt. Így törlésre kerültek a következők:

1. A duplikált kommentek.

2. A magyarázat nélküli kommentek: hordoztok ugyan pozitív vagy negatív értékítéletet, de magyarázatot nem füztek hozzájuk (hangulatjelek, trágár kifejezések). Ezen hozzászólások az elemzés során nehezen értelmezhetők, mivel érvelés hiányában nem derül ki, hogy magára a videóra vonatkoznak vagy az alapjövedelem témakörére.

3. A videó készítőjére vagy a csatorna munkásságára vonatkozó kommentek.

Így a több ezer megjegyzésből 489 kommentet sikerült végleges adatbázisba foglalni. Alapvetően kvalitatív információforrás állt rendelkezésünkre, amit kvantitatív módon is elemezhetővé szükséges tenni. Ehhez nyújt segítséget az előfeldolgozási fázis, melynek során a szöveg normalizálására törekszünk. Az adatelemzés megkönnyítése érdekében a következő lépésben a korpusz tisztítása következett, mivel egy elemzésre alkalmas numerikus adatbázis előállítására van szükség (Németh et al. 2020). Az előfeldolgozás során három fontos eljárást szükséges megvalósítani: tiltólistás szavak eltávolítását, a tokenizálást és a szótövesítést (Mészáros - Sebők 2018, Çoban et al. 2021). A magyar számítógépes nyelvészet egyik meghatározó műhelyéhez kapcsolódik a Magyarlánc nevű program fejlesztése, melyet az MTA-SZTE Mesterséges Intelligencia Kutatócsoportja és annak Nyelvtechnológiai Csoportja dolgozott ki (Zsibrita et al. 2013). A Magyarlánc segítségével végeztük el az előfeldolgozás lépéseit. Ennek első lépésében törlésre kerültek az úgynevezett tiltólistás szavak, melyek nincsenek hatással a mondat jelentésére, mint a kötőszavak, névelők

\footnotetext{
${ }^{6}$ A kutatás által alkalmazott módszertan innovativitásából adódik, hogy nem a megszokott standard eljárások szerint ad lehetőséget a valóság jelenségeinek elemzésére. Azonban a reflexiók, tudattartalmak és viszonyulások, melyek e kutatás alapját adják feltárhatók ezzel a módszerrel.
} 


\section{TEMATIKUS TANULMÁNYOK - Digitális szociológia}

vagy névmások, így nem hordoznak releváns információt az elemzés szempontjából. A szöveg előkészítésének fontos lépése a tokenizálás folyamata is, aminek során a rendelkezésünkre álló megjegyzéseket tokenekre, azaz szavakra bontjuk a szóközök mentén, eltávolítva az írásjeleket. A karaktersorozat (token) a későbbiekben jelentéstani elemzési egységként szolgál. Az előfeldolgozás harmadik lépése Mészáros és Sebők értelmezésében a ragozások eltávolítása, a szótövesítés (stemming). Ezen eljárás során a szó csonkolása történik, ami így előállíthat nem értelmes szavakat is, a magyar nyelv agglutináló nyelvi jellege okán (Mészáros - Sebők 2018). Az előfeldolgozási folyamat elvégzésével rendelkezésünkre állt a tisztított adatbázis.

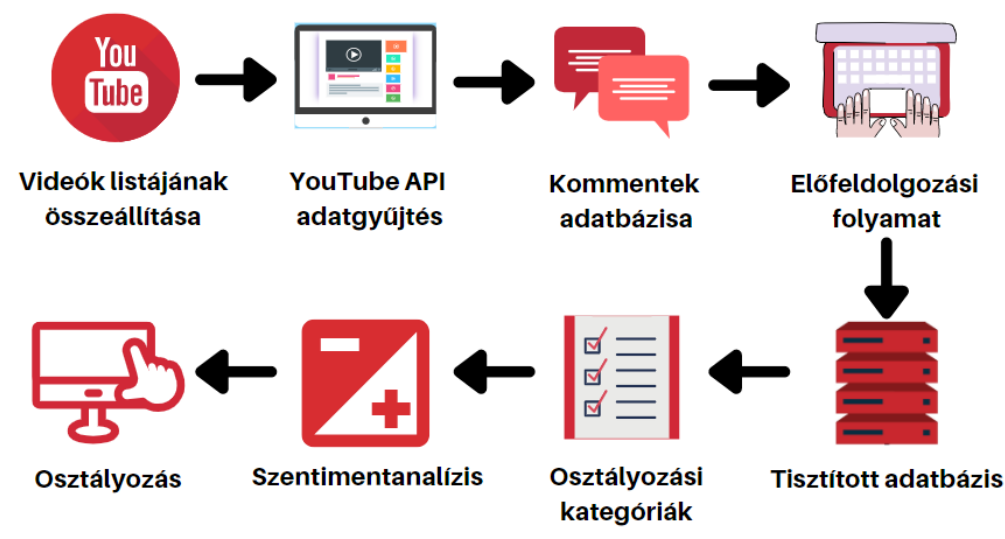

1. ábra. Az elemzési folyamat

Forrás: Saját szerkesztés

Ahogyan az 1. ábra szemlélteti a tisztított adatbázis segítségével következett az elemzés alapjául szolgáló osztályozási kategóriáknak a kidolgozása a szózsák módszerével, a szentimentanalízis és végül a kigyüjtött megjegyzéseknek a kategorizálása az előzetesen előállított osztályozási kategóriákba.

\section{ADATELEMZÉS}

A kutatás adatelemzése során a deduktív módszertant használtuk. Mivel előzetesen kialakítottunk egy előre definiált kategória-rendszert (Mészáros - Sebők 2018). Így a szövegbányászati feladat célja a korpusz elemeinek besorolása volt ezen kategóriákba, az emberi nyelvi tudást ötvözve a számítógépes tudással. Szabadon hozzáférhető szoftverrel végeztük az elemzést, R programnyelvben.

$\mathrm{Az}$ adott dokumentumok jellemzőinek feltárása a szavak és kifejezések gyakoriságával a leghatékonyabb (Mészáros - Sebők 2018). Ennek egyik alapja a szózsák 


\section{TEMATIKUS TANULMÁNYOK - Digitális szociológia}

módszere. Ezen eljárás során az egyes szavak gyakoriságát elemeztük a rendelkezésünkre álló korpuszon belül. Ennek során meghatároztuk a leggyakoribb kifejezéseket, szókapcsolatokat, melyeket 5-5 csoportba soroltunk be negatív és pozitív értékelés alapján. A leggyakoribb kifejezések grafikus ábrázolásához a szófelhő eljárását alkalmaztuk. A YouTube kommentár korpuszában a központi fogalmak megállapításával igyekeztünk választ adni arra a kérdésre, hogy mely kifejezések segítségével történik a feltétel nélküli alapjövedelem hozzászólók általi értelmezése.

A feltétel nélküli alapjövedelemmel kapcsolatban érdekes információkat hordozhat az, hogy a megjegyzések írói milyen álláspontot képviselnek ezen eszközzel kapcsolatban. Ennek eszköze a szentimentelemzés (másnéven szentimentanalízis), ami a szöveg szerzőjének attitűdjeit és véleményét tárja fel (Németh et al. 2020). Ez az elemzés képes megmutatni a vélemények polaritását, így az egyes szövegrészek csoportosíthatóvá válnak pozitív, negatív és semleges kategóriákba. A szentimentanalízis fontos a kommunikáció során, mivel segít megérteni, hogy az adott üzenetre milyen a közvélemény reakciója (Thelwall 2017). Mivel meghatározott számú kategóriába szeretnénk besorolni a szövegrészeket, így a szentimentelemzés is egyfajta osztályozási problémának tekinthető. Ezen természetesnyelv-feldolgozási módszer (NLP módszer) alapját a magyar nyelvre érvényes szentimentszótár képezte (Németh et al. 2020). Az NLP-be minden olyan módszer beletartozik, amelyek nagy mennyiségű, természetes nyelven született szövegek elemzésére alkalmasak lehetnek (Hirschberg - Manning 2015). A véleményelemzés is ehhez járul hozzá. Az elemzésünket a Magyar Szentiment Lexikon segítségével végeztük el, melyben a szavak polaritását meghatározták (Szabó 2014). Ezen szólista 7688 kifejezést tartalmaz, mely biztosította, hogy közel az összes YouTube megjegyzés kategorizálhatóvá váljon a pozitív vagy negatív csoport valamelyikébe. Félig felügyelt módszerként alkalmaztuk ezt az eljárást, hiszen, ahol automatikusan a gép nem tudta kategorizálni az adott szövegrészletet - a köznyelvi megfogalmazás miatt - ott kézi kódolásra tértünk át. A szentimentanalízis során nem alkalmaztunk neutrális csoportot, mivel azt feltételeztük, hogy azon személyek, akik kommentelnek egy előzetesen kiforrott nézettel rendelkeznek, melyet megszeretnének osztani a közvéleménnyel. A szöveg hangulatelemzése hozzájárul ahhoz, hogy megismerjük, hogy a kommentelők körében a feltétel nélküli alapjövedelem kapcsán az elfogadás vagy az elutasítás megítélése a dominánsabb, mivel ez mutatja az elemzett online felület felhasználóinak viszonyulását ezen gazdaságpolitikai eszköz felé.

A szózsák módszerének segítségével kialakított 5-5 csoport alapján és a szentimentanalízis eredményeit alapul véve elvégeztük a kommentek kategóriákba való besorolását, kézi kódolással. Ennek egyik legfőbb előnye, hogy a szöveg kutató általi értő olvasása miatt érvényesebb eredményeket ad, mint egy gépi kódolás esetén (Mészáros - Sebők 2018). Mivel köznyelvben íródott megjegyzések elemzése 


\section{TEMATIKUS TANULMÁNYOK - Digitális szociológia}

képezi a kutatás alapját, így fontos, hogy a kézi kódolás segíti az irónia és a szleng felismerését vagy a közvetett utalásokat is. Annak érdekében, hogy a kutatói szubjektivitás hatását csökkentsük a kézi kódolás esetén kettős vak kódolást alkalmaztunk. A két kódoló, egymástól függetlenül bekategorizálta a letisztított kommenteket az előzetesen meghatározott lista alapján. Majd közösen határozta meg a végső besorolást, megvitatva az önálló kódolás eredményét. Ezzel azonosítva a leggyakrabban megjelenő értékmintákat a feltétel nélküli alapjövedelemmel kapcsolatban, a YouTube platformján.

\section{Eredmények}

KÖZPONTI FOGALMAK ÉS A FELTÉTEL NÉLKÜLI ALAPJÖVEDELEM TÁRSADALMI MEGÍTÉLÉSE A KUTATÁS YOUTUBE KOMMENTÁR KORPUSZÁBAN

Elsőként arra kerestük a választ, hogy melyek azok a fogalmak, amelyek meghatározzák a feltétel nélküli alapjövedelem értelmezését a YouTube általunk vizsgált megjegyzéseiben. Ennek alapja a leggyakoribb kifejezések meghatározása a szózsák módszerével. A 2. ábrán az áttekinthetőség érdekében a 20-nál többször előforduló szavak megjelenítése látható. A szófelhőben a szavak mérete mutatja az előfordulásuk gyakoriságát. A kutatás témája miatt nem meglepő, hogy az „alapjövedelem" kifejezés a legmeghatározóbb az elemzett korpuszban. Ezen túlmenően a szófelhőben három kulcsdimenziót azonosíthatunk. Egyrészt a munkát középpontba állító dimenziót, ahol a „dolgozik”, a „pénz”, az „ingyen” és a „munka” képezi a kulcsfogalmakat. Ezen kifejezés élesen utalnak a jelenlegi társadalmi berendezkedésünkre, melyben a munka központi helyet foglal el az egyének életében. A következő dimenzió a morális kategória, melybe olyan szavak sorolhatók be, mint „ember”, „jog”, „szükség”, „segély”, „társadalmi” és „,szociális”, melyek az előző csoporttól eltérően a feltétel nélküli alapjövedelem morális és jóléti területére utalhatnak. A harmadik dimenzió a nagy rendszerek kategóriája, melybe a „kormány”, „állam” és „,kapitalizmus” szavak tartoznak, szimbolizálva, hogy a feltétel nélküli alapjövedelem témaköre nehezen elválasztható a jelenlegi gazdasági és társadalmi viszonyok értelmezésétől. 


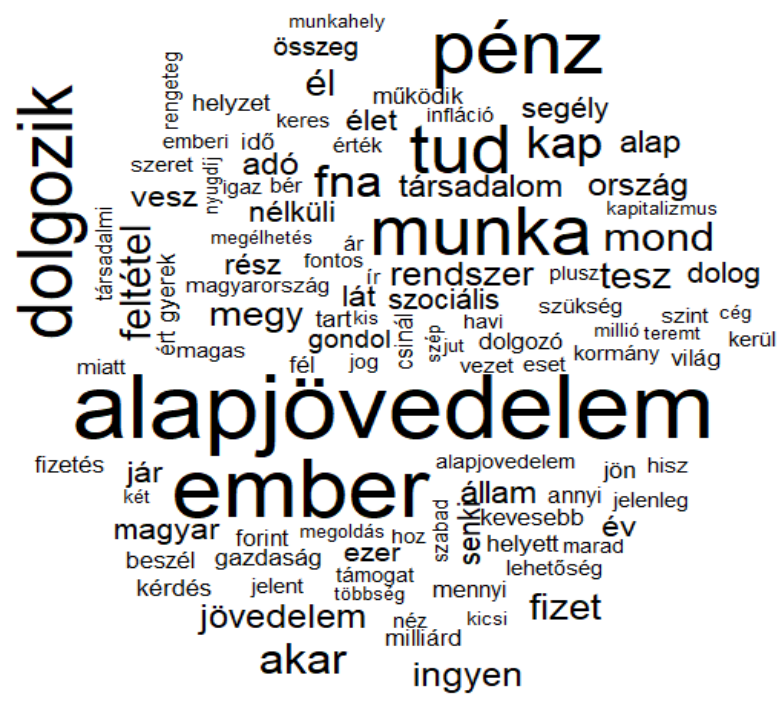

2. ábra. Leggyakoribb szavak grafikus ábrázolása

Forrás: Saját szerkesztés

A szavak és kifejezések megjelenésének gyakorisága szemlélteti a központi fogalmakat a kutatás YouTube kommentár korpuszában. Mivel nem állt rendelkezésre előzetesen a feltétel nélküli alapjövedelem témaköréhez kötődő szólista, ezért egy ilyen típusú eszköz validálása is ezen kutatás során történik. Mivel egy ilyen szólista segíti az egyes megjegyzések osztályozását, és a közöttük lévő logika feltérképezését. A szólista kiindulópontjának a tanulmány elején említett Gilbert és munkatársai által kidolgozott megközelítést tekintjük (Gilbert et al. 2018). Eszerint a feltétel nélküli alapjövedelemhez kapcsolódó viták négy fő kérdés körül bontakoznak ki: a finanszírozhatósági, a morálfilozófiai, a megvalósíthatósági, és motivációbeli kérdések. Így a szólistánk egyik kategóriáját az alapjövedelem fiskális jellemzőihez kötődő megjegyzések képezik. Két dimenzióját különböztetjük meg: megvalósítható, mint pozitív vagy megfizethetetlen, mint negatív dimenzió. A második kategóriát a morálfilozófia szempontok alkotják, melyek elsődlegesen a juttatás feltétel nélküliségéhez kapcsolódnak (két dimenziója: igazságosság és igazságtalanság). Gilbert és munkatársainak harmadik pillérét - megvalósíthatóság - jelen kutatás során két részre bontjuk, mert úgy ítéljük meg, hogy így jobban lefedhető a kérdéskör. Egyrészt az univerzalitás (befogadás és kirekesztés dimenzió) kapcsán felmerülő érdekekre bontható, amely a megvalósítás előzményének nagy kérdése. Másrészt a szubjektív jóléthez (szabadság és másodrangú lét dimenzió) kötődó érvekre, melyek a megvalósítás pszichológiai és társadalmi következményeire vonatkoznak. Az ötödik pillér 


\section{TEMATIKUS TANULMÁNYOK - Digitális szociológia}

esetén a motivációbeli kérdések állnak a középpontban, melyek a normarendszer átalakulásához kötődnek (létjogosultság és teljesítményelvűség dimenzió). Mind az öt kategóriánál megkülönböztethető a pozitív és negatív dimenzió is, ahogyan az elméleti kereteknél is érzékelhető volt a feltétel nélküli alapjövedelem értékelésében meghúzódó kettősség. A csoportok kulcsszavait a 4. és 5. számú ábrák tartalmazzák, amiket a szavak és kifejezések gyakoriságának vizsgálatával állítottunk elő és a kutatás későbbi fázisában ezen csoportokba kategorizáltuk be az egyes megjegyzéseket.

Ezen csoportok polaritását a szentimentanalízis segítségével határoztuk meg, a rendelkezésünkre álló szótár segítségével (Szabó 2014). A 3. ábra szemlélteti, hogy a megjegyzések 66\%-a negatívnak minősül.

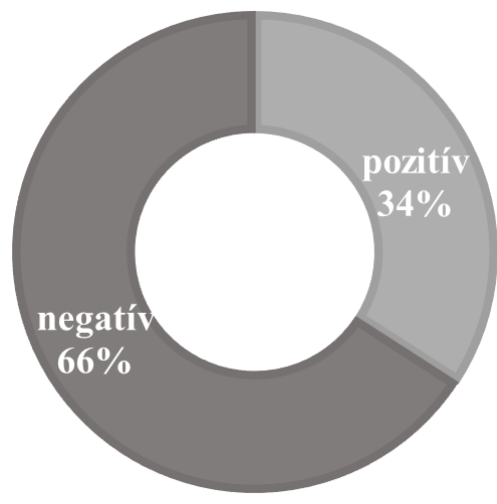

3. ábra. A megjegyzések szentimentanalízisének eredménye (\%) Forrás: Saját szerkesztés

Az alapjövedelemre jellemző pozitív tartalmú kifejezéseket öt csoportba tudtuk besorolni: megvalósíthatóság, befogadás, igazságosság, létjogosultság és szabadság elnevezésekkel illettük ezeket a csoportokat. A 4. ábrán látható, hogy a megvalósíthatóság körébe kerültek azok a szavak, melyek tisztán az alapjövedelem fiskális lehetőségeire utalnak, mint pénznyomtatás, jövedelemadó vagy átcsoportosítás. A befogadás csoportjába az univerzalitás teljes elfogadására jellemző szókapcsolatok kerültek, melyek többek között a következőkkel írhatók le: mindenki, nem segély vagy segítség. Az igazságosság csoportja a feltétel nélküliséghez kötődik, mint alanyi jog vagy keresztényi kötelesség értelmezése. A létjogosultság csoportját, - mely a normarendszer átalakulásának pozitív értelmezését fedi le - olyan kifejezések határozzák meg, mint az örömforrás munkán kívüli keresése vagy az átalakuló munkafogalom. A szubjektív jólét pozitív oldalát a szabadság kérdésköre határozza meg, ahol a méltó élet, a bizalom és a pozitív gondolkodásmód kerül hangsúlyozásra. 
www. metszetek.unideb.hu

\section{TEMATIKUS TANULMÁNYOK - Digitális szociológia}

\section{MEGVALÓSÍTHATÓSÁG \\ megvalósitható; megtakaritás; fokozatosság; lehetséges; átcsoportositás; gazdaságnövelō; adó; AFA; pénznyomtatás; unió; progressziv jövedelemadó}

\section{BEFOGADÁS}

mindenki; rászoruló védelme; elkerülhetetlen; nem segély; segitség; társadalmi hierarchia; minôségi megélhetés

\section{IGAZSÁGOSSÁG}

nem megbélyegzö; alapjog; éhenhalás ellen; emberi jog; alanyi jog; születési jog; keresztényi kötelesség; nem alamizsna

\section{LÉTJOGOSULTSÁG \\ átalakult munkafogalom; robotizáció; kreativitás; örömforrás/ értékteremtés munkán kivül; kötelességérzet; önkéntesség; láthatatlan munka felértékelödése}

\section{SZABADSÁG}

szabadság; méltó élet; élet értelme; būnözés csökkenése; szolidaritás; felszabaditás; stresszmentesség; pozitiv gondolkodásmód; szabadidö; bizalom

4. ábra. A feltétel nélküli alapjövedelem pozitív jegyeinek szólistája Forrás: Saját szerkesztés

A feltétel nélküli alapjövedelem negatív jegyeit szintén öt csoportba tudtuk besorolni, melyek az 5. ábrán látható módon a pozitív jegyek ellentétjeit képezték: megfizethetetlen, kirekesztés, igazságtalanság, teljesítményelvűség és másodrangú lét. A megfizethetetlen csoportba minden olyan kifejezés bekerült, amik az alapjövedelem fiskális elutasítására utalnak: infláció, adósság vagy versenyhátrány. A kirekesztés az univerzalitás teljes elutasítását jelenti, az élősködés és a visszaélés kifejezések hangsúlyozásával. A feltétel nélküliség igazságtalanság dimenzióját a parazita viselkedés és potyautasság szófordulatai határozzák meg. A normarendszer negatív oldala a teljesítményelvűség elnevezést kapta, mely a munkaalapú társadalom és a munka általi értékteremtés szókapcsolataival írható le. A másodrangú lét elnevezésű csoport a szubjektív jólét értelmezéséhez kötődik, mely a polarizációval és az állami függőséggel értelmezhető. 
www. metszetek.unideb.hu

\section{TEMATIKUS TANULMÁNYOK - Digitális szociológia}

\author{
MEGFIZETHETETLEN \\ fiktiv; reménytelen; infláció \\ növelö; drága; államadósság; \\ deficit; nincs fedezet; \\ eladósodottság; gazdasági \\ különbség; versenyhátrány
}

\section{KIREKESZTÉS}

kisebbség; bevándorló; sokgyermekes; gazdag; közmunkás; dolgozni nem akaró; univerzalitás zsákutca; elherdál; élösködés; visszaélés

\section{TELJESÍTMÉNYELVŪSÉG}

munkaalapú; elkényelmesedés; lusta; szenvedés útján; munkavégzés értékteremtés; munka kiváltsága; hivatástudat; ingyen ebéd; vegetáció; siker záloga; megváltoztathatatlan alaptermészet; munka általi elismerés; teljesitménycsökkenés

\section{IGAZSÁGTALANSÁG}

parazita; potyautas; pénz nem megoldás; társadalmi hozzájárulás csökkenése; feltétel szükséges

5. ábra. A feltétel nélküli alapjövedelem negatív jegyeinek szólistája Forrás: Saját szerkesztés

\section{A megjegyzésekre jellemző értékminták}

Az előbbiekben bemutatott szólisták képezik a következőkben bemutatandó osztályozás alapját, mely során kézi kódolás segítségével az egyes kommenteket kategorizáltuk az 5-5 csoport valamelyikébe. A szózsák módszerével előállított szólisták segítségével zajlott az osztályozás. Ennek során arra voltunk kíváncsiak, hogy kimutathatók-e domináns értékminták, melyek a feltétel nélküli alapjövedelemmel kapcsolatos megjegyzések íróit jellemzi. A 6. ábrán láthatóak az egyes kategóriák százalékos megoszlásai: 


\section{TEMATIKUS TANULMÁNYOK - Digitális szociológia}

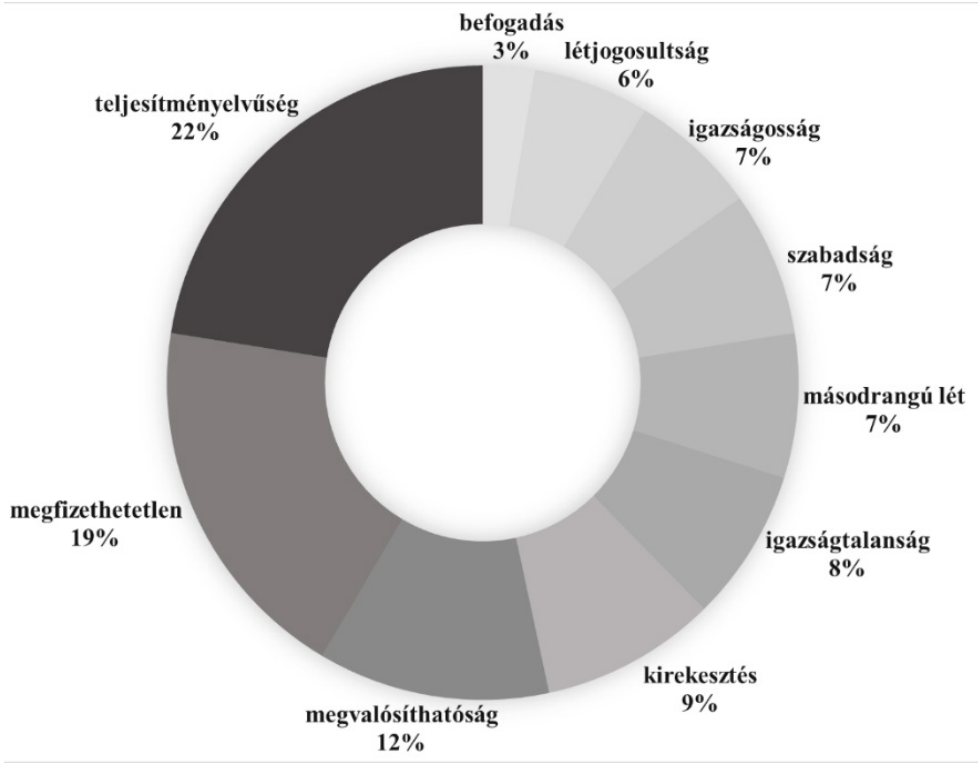

6. ábra. A megjegyzésekre jellemző értékminták megoszlása (\%)

Forrás: Saját szerkesztés

A finanszírozáson belül a két szélsőséges álláspontot a megvalósíthatóság lehetősége és a megfizethetetlenség alkotja. A második és a harmadik legjellemzőbb értékekről van szó az osztályozás eredménye szerint, tehát a finanszírozhatóság kérdésköre foglalkoztatja leginkább a kommentelőket. Mivel az elemzett megjegyzések 19\%-a ítéli meg úgy, hogy a feltétel nélküli alapjövedelem megfizethetetlen. 12\%a azonban pozitívan tekint az alapjövedelem finanszírozhatóságára és megvalósíthatónak tartja azt.

A legnagyobb arányban a hozzászólókra a teljesítményelvűség hangsúlyozása jellemző, mely mellé úgy tűnik az alanyi jog nehezen párosulhat. A normarendszer megváltozásának két végpontja között ugyanis a legnagyobb a szakadék a többi vizsgált kategóriához képest. Hiszen a teljesítményelv 22\%-a, kerül szembe a létjogán elv elfogadottságának 6\%-os értékével.

Meglehetősen nagy különbség tapasztalható az univerzalitás két értéke között is, mivel a kirekesztés a negyedik leggyakoribb pontja az alapjövedelemmel szembeni negatív értékítéleteknek, a maga 9\%-ával, míg ennek ellentéte, a befogadás a legkisebb értéket képviseli, elenyésző $3 \%$-kal.

A feltétel nélküliség esetén a kommentelők a két végpont értékeit közel azonos arányban támogatták: az igazságtalanság 8\%, míg az igazságosság 7\%-ban jelent meg az érvelések során. 


\section{TEMATIKUS TANULMÁNYOK - Digitális szociológia}

A szubjektív jólét két értéke a másodrangú lét (7\%) és a szabadság (7\%) azonos arányban merültek fel a megjegyzések között.

A 6. ábrán az is szembetűnő, hogy a pozitív érvek merülnek fel kisebb arányban a megjegyzésekben, mivel a befogadás, a létjogán elv, az igazságosság és a szabadság a legkisebb arányban előforduló dimenziók. A pozitív érvek közül a legmagasabb támogatottságot a megvalósíthatóság képezi (12\%), ami elszakadt a többi pozitív érvcsoporttól és bekerült a negatív szempontok közé, melyek jóval gyakrabban merülnek fel, mint a pozitív megközelítésű kategóriák. Így a másodrangú lét, igazságtalanság, kirekesztés, megfizethetetlenség és a teljesítményelvűség dimenziója kerül az élmezőnybe.

\section{Diskurzus}

\section{A FELTÉTEL NÉLKÜLI ALAPJÖVEDELEM MEGÍTÉLÉSE}

Az elemzett válaszok 66\%-a negatív értékelő véleményt tartalmazott, és csak 34\%-a fejezte ki támogatását ezen eszköz valamely tulajdonságával kapcsolatban. Annak oka, hogy közel kétszerese a negatív értékítélet a pozitív hozzáállásnak az lehet az oka, hogy a médiában az újszerünek és kiszámíthatatlannak tűnő témák a társadalom idealizált rendjét veszélyeztető kockázatként kerülnek feldolgozásra (Kitzinger 2000). A feltétel nélküli alapjövedelem kettős értelemben is bizalmatlanságot vált ki az egyénekből. Egyrészt bevezethetősége számtalan kérdést vet fel, az ezen eszközzel kapcsolatos diskurzusok tele vannak kételyekkel és megválaszolatlan kérdésekkel. Másrészt ezek a kérdések az emberi élet egyik legkényesebb és legmeghatározóbb területéhez, az egzisztenciához kapcsolódnak. Az emberek életében a fenyegetettség érzése az egzisztenciális kiszolgáltatottság kérdéskörében a legerősebb, hiszen emberi természetünkből ered létfenntartásunkra való állandó törekvésünk (Policy Agenda 2018). Ennek értelmében a negatív értékítélet magas aránya logikus reakcióként mutatkozik a kommentelők válaszaiban.

A leggyakoribb szavak grafikus ábrázolása is alátámasztja, hogy a megjegyzések az egzisztenciális biztonságra fókuszálnak. A javak elosztásának terén kétféle elosztórendszerről beszélhetünk, egyrészt a piaci rendszerről, másrészt a jóléti állam által megvalósított újraelosztásról (Örkény - Székelyi 2011). Ez a kettősség jelenik meg a szófelhő esetében is. Egyrészt bizonyos szavak a munkaerőpiac révén elérhető egzisztenciát szimbolizálják (dolgozik és munka kifejezések), másrészt megjelenik a megélhetés biztosításához szükséges jóléti hozzájárulás szükségessége is (jog, segély és szociális kifejezések). 


\section{TEMATIKUS TANULMÁNYOK - Digitális szociológia}

\section{EGZISZTENCIÁLIS BIZTONSÁGRA HATÓ ERŐK: NORMARENDSZER ÉS FINANSZÍROZHATÓSÁG}

Az osztályozás során láthatóvá vált, hogy a feltétel nélküli alapjövedelemmel kapcsolatban a legjellemzőbb értékminta a teljesítményelvűség hangsúlyozása (22\%) és a megfizethetetlenségére való hivatkozás (19\%). Ez a két negatív értékminta is szorosan kötődik az egzisztenciális biztonsághoz. A teljesítményelvűség (normarendszer negatív dimenziója) kapcsán az a félelem fogalmazódik meg a kommentekben, hogy az alapjövedelem teljesítménycsökkenést és lustaságot eredményezne a társadalomban. A megfizethetetlenség (finanszírozhatóság negatív dimenziója) kapcsán erőteljes ellenállás figyelhető meg az alapjövedelem fiskális lehetőségeivel kapcsolatban.

A jelen kutatás alapjául szolgáló megjegyzésekben a munkavégzést szorosan öszszekapcsolják az értékteremtéssel és a hivatástudattal. A magyar ember jellemzően munkacentrikus (Kapitány - Kapitány 2014), így a munka általi elismerés és siker elsődleges szerepet játszik életünkben, melyek a kommentekben is hangsúlyozásra kerültek. A társadalom azt ismeri el, aki dolgozik, mivel a társadalom középpontját képezi a munka. Ez a fajta munka-felfogás alapvetően jellemző a kommentekre. Ezért a megjegyzések íróinak nagy százaléka csak munkaalapú társadalomban képes gondolkodni, amivel a feltétel nélküli alapjövedelemmel járó kevesebb munkaórát és teljesítménycsökkenést nem tekintik összeegyeztethetőnek.

Kapitányék lehetséges megoldásnak látják a kilépés-kivonulás lehetőségét a munka túlcentralizált rendszeréből (Kapitány - Kapitány 2014). Ennek következtében erősödne a saját lábra állás jelentősége, mely során az egyén saját céljait követheti, szabadon választható tevékenységeivel, ami javítja teljesítményét és nagyobb kielégülést eredményez számára. A saját lábra állás a kistermelő vagy kisvállalkozó pozíciókkal és az értelmi munka végzésével lehetséges. A feltétel nélküli alapjövedelem esetén a létjogosultság elnevezésű értékminta csoportban (normarendszer pozitív dimenziója) a munkának ez a szabadabb formája fogalmazódik meg, az átalakult munkafogalomra való hivatkozással.

A szabadabb munka egyik alapfeltétele a belső motiváció az adott tevékenység elvégzésére (Kapitány - Kapitány 2014). Keynes megítélése szerint a belső késztetés arra sarkallja az egyént, hogy jobban kedvelje a cselekvést, mint a tétlenkedést (Keynes 1965). A feltétel nélküli alapjövedelem létjogosultság kategóriájának értelmezésekor nem a munka értékeinek felszámolódása látható, hanem a munka elsődleges szerepének fellazulása. A létjogosultság típusú megközelítést meglehetősen alacsony arányban képviselték a kommentek írói (6\%), mivel a jelenlegi gazdasági és társadalmi rendszerben a szabad munkafelfogás távolinak tűnik. Ennek oka, hogy a piaci viszonyok és a politikai rendszer működése nem kedvez a munka szabadságának (Kapitány - Kapitány 2014). Honneth (2009) ezzel összefüggésben arra hívja fel a figyelmet, hogy a munka világától való intellektuális elfordulás ten- 


\section{TEMATIKUS TANULMÁNYOK - Digitális szociológia}

denciájával a népesség általános hangulata nincs összhangban, mivel a népesség nagy része még mindig a munkafolyamatban betöltött szerepe alapján jelöli meg társadalmi identitását. Ez eredményezte a teljesítményelvűség értékének dominanciáját a létjogán elvvel szemben.

A szabadabb munkafelfogással ellentétben a finanszírozhatóság pozitív dimenziója - a megvalósíthatóság - jóval nagyobb támogatottságot kapott (12\%). Átcsoportosításokkal vagy az adórendszer átalakításával tartják megvalósíthatónak a feltétel nélküli alapjövedelem összegét. Ennek alapja lehet, hogy amennyiben az alapjövedelem csökkenti a meglévő szociális védelmi rendszerek bürokratikus kiadásait és összetettségüket, akkor az pozitívan hathat a fiskális megvalósíthatóságára is (Hir$\operatorname{sch} 2015)$.

\section{ÉRDEKEK METSZETÉBEN}

A negyedik leggyakrabban felmerülő kategória a kirekesztés (univerzalitás negatív dimenziója). A kommentek 9\%-ára erőteljes bűnbakképzési mechanizmus jellemző. Ez egyfajta tömeglélektani jelenségnek tekinthető, melynek során pontosan azon egyéneket nevesítik meg a problémák okozóiként, akik azokat a társadalmi problémákat legnagyobb arányban elszenvedik (Csoba 2011). Ez a mechanizmus általában nem bizonyított tényeken nyugszik, sokkal inkább előítéleteken alapszik. A hozzászólok erőteljesen a kisebbség tagjait rekesztenék ki a feltétel nélküli alapjövedelem köreiből. E csoportba tartozónak tekintik a sokgyermekes családokat és a közmunkásokat is, akiket érdemtelennek bélyegeznek meg egy univerzális típusú juttatásra.

Mivel a munkaalapú társadalom fontos meghatározója az emberek gondolkodásának, így ezen csoportokkal a kommentelők elsődleges problémája a munkanélküliségük. A munkanélkülieket elsősorban azért érik támadások, mert a társadalom többi tagja úgy ítéli meg, hogy a szociális ellátásaikkal kivonják magukat a társadalmi kötelezettségeik alól és nem kapcsolódnak be a társadalmi értékek termelésébe (Csoba 2011).

Castel megítélése szerint a ressentiment érzése az irigység és megvetése keveréke (Castel 2005a). Az, hogy ez az érzés a társadalmi helyzetkülönbségből táplálkozik, oda vezet, hogy az egyén saját balszerencséjéért a társadalmi hierarchiában vagy a közvetlenül alatta, vagy a közvetlenül fölötte álló társadalmi csoportot okolja. A ressentiment érzése olyan erős frusztrációt vált ki, mely védekező attitűdöket alakít ki az egyénben, aminek következtében bármilyen újdonságot idegennek tekintenek és elzárkóznak a pluralizmus elől, a különbségeket ezek értelmében nem hajlandóak tolerálni. A kirekesztés kategóriáján belül a hozzászólók a bevándorlók - mint közvetlenül alattuk - és a jómódúak - mint közvetlenül felettük - társadalmi csoportját nevezik meg, akiknek semmilyen körülmények között nem adnának alapjövedelem 


\section{TEMATIKUS TANULMÁNYOK - Digitális szociológia}

típusú juttatást. A magas jövedelműeket nem tartják rászorulónak egy univerzális juttatásra (Tanner 2015, Piachaud 2016). A bevándorlók kirekesztésének igényét a bevándorlásellenes politikai retorika is erősíthette. 2010-től Magyarországon bevándorlásellenes retorika volt megfigyelhető (Dessewffy et al. 2018).

Az erőteljes kirekesztő hozzáállással szemben az univerzalitás pozitív dimenziójára - befogadás - elenyésző utalás történt, csupán 3\%-a az elemzett mintának. A megjegyzésekben erőteljesebben van jelen az univerzalitástól való elzárkózás, a bizonyos típus emberek kirekesztése, mint a mindenkit befogadó attitűd.

A feltétel nélküliség kategóriájának két dimenziójában már nem tapasztalható ekkora megosztottság a hozzászólások között (igazságtalanság - 8\%, igazságosság - 7\%). Az univerzalitás kategória befogadás dimenziójának alacsony aránya miatt meglepő, hogy a feltétel nélküliség kategória igazságosság dimenziója kétszeres jelentőségre tett szert. Ennek keretében ugyanis a hozzászólók úgy ítélik meg, hogy a jóléti állam által megvalósított újraelosztásra szükség van. Ennek segítségével elkerülhető a társadalmi leszakadás, biztosítható az állampolgárok jóléte, a társadalmi egyenlőtlenségek csökkentése, vagy a méltó emberi élethez való feltételek megteremtése (Örkény - Székelyi 2011).

Örkény és Székelyi vizsgálatában rekonstruálta, hogy mit tartanak az emberek igazságosnak és igazságtalannak, és milyen elveket választanak akkor, amikor egy igazságosabb világról beszélnek (Örkény - Székelyi 2010). Jellemző, hogy a legelfogadottabb igazságossági elvnek az individualista irányultságú ideológia bizonyult (egyéni teljesítmény és érdem hangsúlyozása, rendszer a semlegesség és az esélyegyenlőség elvén nyugszik) és az egalitarianizmus is viszonylag magas arányban elfogadott (egyenlőtlenségek mérséklődnek, állam normatív szabályozójává válik a társadalmi elosztásnak, kollektív intézményi felelősség hangsúlyozása). A korábban hangsúlyozott munkaalapú társadalom magas támogatottságát igazolja Örkény és Székelyi vizsgálata is, miszerint a legigazságosabb elv az individualista irányultságú ideológia. Ennek keretében az egyéni teljesítmény és érdem kerül hangsúlyozásra a társadalom múködésében. A feltétel nélküliség kategória két dimenziójának egymáshoz közeli értékét az individualista elv elsődlegessége és az egalitarianizmus elvének erős, de nem domináló pozíciója indokolja. Az igazságtalanság dimenzión belül az individualista igazságossági elv érvényesülése látszik, mivel képviselői hangsúlyozzák, hogy a rendszer a semlegesség és az esélyegyenlőség elvén nyugszik, így mindenkinek egyenlő esélye van előbbre jutni. A jogokat pedig nem lehet ab ovo szavatolni, mert az csak a társadalmi hozzájárulás csökkenését eredményezné. Az igazságosság dimenzió kevéssé marad el az igazságtalanság dimenziója mellett, ennek oka az egalitarianizmus igazságossági elv erős, de nem domináló pozíciója lehet. Ennek keretében az egyenlőtlenségek mérséklődésére kerül a hangsúly és arra, hogy az állam normatív szabályozójává válik a társadalmi elosztásnak. Ennek értelmében a megjegyzések arra vonatkoznak, hogy a feltétel nélküliség igazságos mivel képes megakadályozni a szegénységet és a társadalmi leszakadást. A két elv 


\section{TEMATIKUS TANULMÁNYOK - Digitális szociológia}

hangsúlyos volta a társadalmon belül, megnehezíti a feltétel nélküli alapjövedelem megítélését az igazságosság szempontjából.

\section{A GONDOLKODÁSUNK BÉKLYÓI}

A szubjektív jólét kategória két dimenziója - mind a szabadság, mind a másodrangú lét 7\% - megegyező arányban fordult elő a megjegyzésekben. A szabadság körébe tartozó értékek - mint szolidaritás, bizalom vagy pozitív gondolkodásmód - a feltétel nélküli alapjövedelem szubjektív jólét terén bekövetkező pozitív változásait takarja. Ezzel szemben a másodrangú lét során a függőség és a polarizáció erősödő folyamatai kerültek hangsúlyozásra. A másodrangú lét a legalacsonyabb arányban előforduló negatív dimenzió lett. Ennek oka az lehet, hogy az egyén először arra törekszik, hogy az anyagi jellegű, létbiztonsággal kapcsolatos szükségleteit kielégítse, ezek kielégítése után következhet a magasabb rendű szükségletek felismerése (Inglehart - Flanagan 1987). Az élet anyagi dimenzióinak biztosítása jobban foglalkoztatja az embereket - ami a finanszírozhatósághoz és a munkavállalás normájának átalakulásához kötődik - mint a magasabb rendű igények megfogalmazása, amelyek nehezebben azonosíthatók.

Magyarország a zárt gondolkodás jegyeit mutatja (Keller 2009). Ezek megfigyelhetőek abban, hogy kevésbé tartjuk fontosnak a civil és politikai szabadságjogokat, kisebb mértékű a mindennapi aktív politikai szerepvállalásunk, kevésbé toleráljuk a másságot, így kevésbé is bízunk másokban, illetve értékeinkben kisebb szerepet szánunk az önmegvalósítási értékeknek. Ezek a jellemzők azt eredményezik, hogy a szabadság kérdésköre nem válik dominánsabbá a másodrangú lét szempontjaihoz képest.

A szubjektív jólét esetén szemben áll egymással, azaz érv, hogy az alapjövedelem nagyobb fokú szabadságot képes garantálni és az, hogy az állami szerepvállalástól való függőség növekedne. A jóléti rendszerek neoliberális kritikái szerint az állam növekvő szerepvállalása olyan rendszerhez vezet, amely korlátozza az egyén szabadságát (Tomka 2008). Egyrészt azért, mert a kötelező biztosítások ellentétesek az egyén választási szabadságával, másrészt a nagy adóelvonások és progresszív adók rendszere a tulajdonnal való rendelkezés jogát sértik. Hayek szerint a jóléti állam aláássa a piac hatékony müködését, mivel a sikeresek vagyonát elveszi, míg ezzel párhuzamosan meghosszabbítja a rászorultak függőségét (Hayek 1978). Értelmezésében az állami beavatkozást szükséges minimálisra redukálni, annak érdekében, hogy az államtól való függést ne erősítse.

Nagy kérdés tehát, hogy ha az alapjövedelem bevezetésre kerülne, akkor az emberek képesek lennének-e élni az általa biztosított nagyobb szabadsággal és a magyar társadalom képes lenne-e erőteljesebben képviselni a posztmateriális értékeket? Vagy a másodrangú lét függőségi állapotába süllyednénk-e, a zárt gondolkodás, gondolkodásmód korlátaiba ütközve? 


\section{TEMATIKUS TANULMÁNYOK - Digitális szociológia}

\section{Összegzés}

A tanulmányban a feltétel nélküli alapjövedelemre fókuszáltunk, mely napjainkban a gazdasági és társadalmi folyamatok változásaival párhuzamosan egyre nagyobb figyelmet kap. Az ezen eszközzel kapcsolatos értékeket és véleményeket igyekeztünk feltárni a YouTube ilyen témájú videóinak kommentszekciójában. Kutatásunk vegyes módszerrel dolgozik, mivel az adatok gyüjtése, tárolása, szentimentanalízise és a szózsák módszere informatikai eljárásokkal valósult meg, míg a kategorizálás kézi kódolás révén, kutatói eljárás eredménye.

A leggyakoribb szavak grafikus ábrázolása azt mutatja, hogy a megjegyzések az egzisztenciális biztonságra fókuszálnak. Ez az a témakör, amely leginkább foglalkoztatja a kommentelőket az alapjövedelem témakörével kapcsolatban. Egyrészt bizonyos szavak a munkaerőpiac révén elérhető egzisztenciát szimbolizálják (dolgozik és munka kifejezések), másrészt megjelenik a jóléti hozzájárulás területe is (jog, segély és szociális kifejezések).

A YouTube megjegyzések kapcsán arra is kíváncsiak voltunk, hogy milyen megítélés alá esik a feltétel nélküli alapjövedelem, illetve jellegzetes értékmintákat igyekeztünk kirajzolni, melyek az elemzett online felület felhasználóinak viszonyulását fejezi ki ezen eszközzel kapcsolatban. A kutatás eredményének tekinthető, hogy az alapjövedelemre jellemző pozitív tartalmú kifejezéseket öt csoportba tudtuk besorolni: megvalósíthatóság, befogadás, igazságosság, létjogosultság és szabadság elnevezésekkel illettük ezeket a csoportokat. A feltétel nélküli alapjövedelem negatív jegyeit szintén öt csoportba tudtuk besorolni: megfizethetetlen, kirekesztés, igazságtalanság, teljesítményelvűség és másodrangú lét. A negatív csoport közel kétszerese volt a pozitív tartalmú megközelítéseknek. Ezek a csoportok a finanszírozhatóság, univerzalitás, feltétel nélküliség, normarendszer és szubjektív jólét egy-egy dimenzióját alkották.

A finanszírozás központi kérdéskörnek tekinthető a feltétel nélkülialapjövedelem kapcsán, mivel mind a pozitív, mind a negatív értékek jelentős arányban merültek fel a megjegyzésekben. Ennek a kategóriának a felértékelődése az egzisztencia fontosságát mutatja az emberek életében.

A feltétel nélküli alapjövedelem munkavállalási motivációra gyakorolt hatását nemcsak a szakirodalmak, de a kommentelők is központi helyre helyezik. A legnagyobb arányban a hozzászólókra a teljesítményelvűség hangsúlyozása jellemző. A normarendszer megváltozásának két végpontja között a legnagyobb a szakadék a többi vizsgált kategóriához képest. A teljesítményelvűség hangsúlyossága azzal magyarázható, hogy a munka általi elismerés elsődleges szerepet játszik életünkben.

Az alapjövedelem harmadik legsarkalatosabb pontja az univerzalitás elfogadottsága, mivel ezen a területen a támogatók aránya eltörpül az ellenzőkkel szemben. A megjegyzésekben erőteljesebben van jelen az univerzalitástól való elzárkózás, bizonyos emberek kirekesztése, mint a mindenkit befogadó attitűd. 


\section{TEMATIKUS TANULMÁNYOK - Digitális Szociológia}

A feltétel nélküliség és a szubjektív jólét két-két dimenziója között nem érzékelhetünk jelentős különbségeket, ennek az lehet az oka, hogy ezek a típusú érvek és ellenérvek másodlagos kérdésként merülnek fel az emberek gondolkodásában, amelyek gyökerei a normarendszer és az univerzalitás terén fogalmazódnak meg.

Jövőbeli kutatások kiindulópontját képezhetik a jelen kutatás során összeállított osztályozási kategóriák. Az eszköz használatával a Big Data-alapú elemzések, így a későbbiekben erőteljesebben támaszkodhatnak a gépi tanulás eszközeire.

\section{Irodalom}

Artner A. (2014): A feltétel nélküli alapjövedelem relevanciája és kérdőjelei. Eszmélet, 102: 109-130.

Baksay G. - Bókay M. - Palotai D. - Szalai Á. (2017): A feltétel nélküli alapjövedelem árnyoldalai. Magyar Nemzeti Bank Kiadványa

Beck, U. (2010): A munka szép új világa. Belvedere Meridionale Kiadó, Szeged

Ben-David, A. (2020): Counter-archiving Facebook. European Journal of Communication, 35(3): 249-264. oldal, https://doi.org/10.1177/0267323120922069

Bergmann, B. R. (2004): A swedish-style welfare state or Basic Income: Which should have priority? Politics \& Society 32: 107-118. oldal, https://doi. org/10.1177/0032329203261101

Castel, R. (2005a): A társadalmi biztonság elvesztése. Mit jelent védetten élni? Esély, 4: 42-65.

Castel, R. (2005b): A társadalmi biztonság elvesztése. Mit jelent védetten élni? Esély, 6: 3-22.

Çoban, Ö. - Özel, S. A. - İnan, A. (2021): Deep Learning-based Sentiment Analysis of Facebook Data: The Case of Turkish Users. The Computer Journal, 64(3): 473499., https://doi.org/10.1093/comjnl/bxaa172

Csoba J. (2011): Munkaerô-piaci változások, leszakadó társadalmi csoportok. Debreceni Egyetem Szociológia és Szociálpolitika Tanszék, Debrecen

Dessewffy T. - Mezei M. - Naszályi N. (2018): Harry Potter, avagy a politikai bölcsek köve? Populáris kultúra és politikai aktivizmus. Politikatudományi Szemle, XXVII/4: 105-130. oldal

Dubovi, I. - Tabak, I. (2021): Interactions between emotional and cognitive engagement with science on YouTube. Public Understanding of Science, 1-18., https:// doi.org/10.1177/0963662521990848

Fromm, E. (2002): Menekülés a szabadság elől. Napvilág Kiadó, Budapest

Gilbert, R. - Murphy, N. A. - Stepka, A. - Barrett, M. - Worku, D. (2018): Would a basic income guarantee reduce the motivation to work? An analysis of labor respon- 


\section{TEMATIKUS TANULMÁNYOK - Digitális szociológia}

ses in 16 trial programs. Basic Income Studies, 13(2): 1-12. oldal, https://doi. org/10.1515/bis-2018-0011

Graeber, D. (2018): Bullshit Jobs: A Theory. Simon \& Schuster, New York

Hayek, F. (1978): Law, Legislation and Liberty. Volume 2: The Mirage of Social Justice. University of Chicago Press, Chicago

Sachs, J. (2015): Investing in Social Capital. In: Helliwell, J. - Layard, R. - Sachs, J. (szerk): World Happiness Report 2015. Sustainable Development Solutions Network, New York, 152-167.

Hirsch, D. (2015): Could a 'citizen's income' work? Joseph Rowntree Foundation Programme Paper, York

Hirschberg, J. - Manning, C. D. (2015): Advances in natural language processing. Science, 349(6245): 261-266. oldal, DOI: 10.1126/science.aaa8685

Honneth, A. (2009): Munka és elismerés. Kísérlet egy újrafogalmazásra. Replika, 68: 125-140.

Hradil, S. (1995): Régi fogalmak és új struktúrák. Miliō-, szubkultúra- és életstíluskutatás a 80-as években. In: Andorka R. - Hradil, S. -Peschar, J. L. (szerk.): Társadalmi rétegződés. Aula, Budapest, 347-385.

Inglehart, R. - Flanagan, S. C. (1987): Value Change in Industrial Societies. The American Political Science Review, 81: 1289-1319. oldal, https://doi.org/ 10.2307/1962590

Kapitány Á. - Kapitány G. (2014): Alternatív életstratégiák kulcselemei. Magyar Lettre Internationale, 98: 64-70.

Keller T. (2009): Magyarország helye a világ értéktérképén. Tárki, Budapest

Keynes, J. M. (1965): A foglalkoztatás, a kamat és a pénz általános elmélete. KJK, Budapest

Khan, M. L. (2017) Social media engagement: What motivates user participation and consumption on YouTube? Computers in Human Behavior, 66: 236-247. https://doi.org/10.1016/j.chb.2016.09.024

Kitzinger D. (2000): A morális pánik elmélete. Replika, 40: 23-48. oldal

Lucas, M. - Gunawardena, C. - Moreira, A. (2014): Assessing social construction of knowledge online: A critique of the interaction analysis model. Computers in Human Behavior, 30: 574-582. oldal, https://doi.org/10.1016/j.chb.2013.07.050

Mészáros E. - Sebők M. (2018): A szövegbányászati módszerek alkalmazásának lehetőségei a joggyakorlat-elemzésben. Forum Sententiarum Curiae, 2: 6-12.

Németh R. - Katona E. R. - Kmetty Z. (2020): Az automatizált szövegelemzés perspektívája a társadalomtudományokban. Szociológia Szemle, 30(1): 44-62. 


\section{TEMATIKUS TANULMÁNYOK - Digitális Szociológia}

Örkény A. - Székelyi M. (2010): Az igazságosság labirintusaiban. Szociológia Szemle, 20(2): 4-41.

Örkény A. - Székelyi M. (2011): A nagy elosztási rendszerekről vallott nézetek generációs vonatkozásai. In: Örkény A. - Székelyi M. (szerk.): Az igazságosság labirintusaiban. Társadalmi méltányosság és generációs igazságosság a 21. század Magyarországán. Sik Kiadó, Budapest, 91-105.

Piachaud, D. (2016): Citizen's Income: rights and wrongs. Centre for Analysis of Social Exclusion. London School of Economics, London

Policy Agenda (2018): Félelmek a munka világában.

Reilly, P. (2014): The 'Battle of Stokes Croft' on YouTube: The development of an ethical stance for the study of online comments. Sage Research Methods Cases Part 1. https://dx.doi.org/10.4135/978144627305013509209

Salganick, M. J. (2017): Bit by Bit: Social Research in the Digital Age. Princeton University Press, Princeton

Schopenhauer, A. (1992): A nemi szerelem metafizikája. Az élethez való akarat igenlésérôl. Az élet semmiségérôl es gyötrelmérôl. Reprint: Hatágú Síp Alapítvány, Budapest

Szabó M. K. (2014): Egy magyar nyelvü szentimentlexikon létrehozásának tapasztalatai. In: Nyelv, kultúra, társadalom konferencia, Budapest

Szelényi I. (2014): Variációk a szegénység témára. In: Kolosi T. - Tóth I. Gy. (szerk.): Társadalmi Riport 2014. Tárki, Budapest, 629-635.

Tang, L. - Fujimoto, K. - Amith, M. T. - Cunningham, R. - Costantini, R. A. - York, F. - Tao, C. (2021): "Down the Rabbit Hole” of Vaccine Misinformation on YouTube: Network Exposure Study. Journal of Medical Internet Research, 23(1): 1-9., doi:10.2196/23262

Tanner, M. (2015): The pros and cons of a guaranteed national income. Cato Institute Policy Analysis, 773: 1-35.

Thelwall, M. (2017): The heart and soul of the Web? Sentiment strength detection in the social Web with sentistrength. In: Holyst, J. (szerk.): Cyberemotions: Collective Emotions in Cyberspace. Understanding Complex Systems. Springer, Berlin, 119134.

Tomka B. (2008): A jóléti állam Európában és Magyarországon. Corvina Kiadó, Budapest

Van Parijs, P. (2010): Alapjövedelem: egy egyszerű és erőteljes gondolat a huszonegyedik század számára. Esély, 5: 9-41.

Weber, M. (1982): A protestáns etika és a kapitalizmus szelleme. Gondolat Kiadó, Budapest 


\section{TEMATIKUS TANULMÁNYOK - Digitális Szociológia}

Zsibrita, J. - Vincze V. - Farkas R. (2013): magyarlanc: A Toolkit for Morphological and Dependency Parsing of Hungarian. In: Proceedings of RANLP 2013, 763771. 